\title{
TINJAUAN ETIKA KRISTEN \\ TERHADAP OPERASI TRANSEKSUAL
}

\author{
I Wayan Purnama \\ sttjaffraymakassar@yahoo.co.id \\ Simon Alexander Tarigan \\ Tarigan_simon@yahoo.com
}

\begin{abstract}
ABSTRAK
Adapun tujuan penulisan dari pokok masalah diatas adalah: Untuk mengetahui pandangan etika Kristen tentang operasi transeksual.

Mengingat begitu luasnya pembahasan tentang transeksual secara umum maka penulis membatasi karya ilmiah ini hanya berfokus pada operasi transeksual. Pembahasan operasi disini juga dibatasi hanya operasi alat kelamin ditinjau dari etika Kristen. Etika yang digunakan dalam penulisan ini dibatasi hanya etika yang bersifat deontologis.

Berdasarkan pembahasan yang telah dikemukakan oleh penulis dalam karya ilmiah ini maka penulis menyimpulkan. Pertama, tubuh, seks, jenis kelamin, dan kepuasan seksual, pada dasarnya diciptakan Allah sangat baik, mulia dan suci dan dengan tujuan yang baik, dan ini juga merupakan gambar Allah. Akibat kejatuhan manusia pertama kedalam dosa maka gambar Allah menjadi rusak, sehingga Tubuh, seks, jenis kelamin, kepuasan seksual kehilangan peranannya. Banyak penyimpangan seksual yang berkembangan saat ini, dan sudah sangat meresahkan di dalam masyarakat. Kedua, transeksual adalah salah satu bentuk kelainan seksualitas yang abnormal dimana seorang penderita mengalami ganguan identitas gender, yaitu seseorang merasa terjebak dalam tubuh yang berbeda. Ketiga, secara etika Kristen menjadi seorang transeksual atau waria tidak menjadi masalah. Karena secara Alkitabiah ada orang yang terlahir dengan keadaan abnormal. Perilaku homoseksual bagi seorang transeksual secara Alkitabiah dilarang karena melanggar prinsip Alkitab. Keempat, segala bentuk tindakan operasi transeksual yang mementingkan keegoisan dan kenikmatan belaka dari segi etika Kristen adalah salah dan melanggar kaidah Tuhan yang sudah ditetapkan. Seorang yang melakukan operasi transeksual sudah menghina dan tidak menghargai dan juga tidak mengucap syukur atas apa yang sudah diberikan Tuhan yaitu kodrat sejak lahir sebagai laki-laki maupun perempuan. Seorang yang melakukan operasi transeksual akan mempunyai prilaku homoseksual. Kelima, orang kristiani harus dapat menampung dan menerima mereka sebagai bagian dari tubuh Kristus, mungkin Tuhan punya rencana bagi kaum transeksual yang rohani untuk menjadi penginjil kaum transeksual.
\end{abstract}

Kata Kunci: Etika Kristen, Orerasi Transeksual 


\section{PENDAHULUAN}

\section{Latar Belakang Masalah}

Manusia merupakan ciptaan Allah yang paling sempurna dari segala yang diciptakan-Nya. Manusia diciptakan dengan maksud-maksud besar Allah dalam dunia ini. Allah menciptakan manusia dalam dua kodrat yang berbeda yaitu kodrat sebagai laki-laki dan kodrat sebagai perempuan. (Kejadian 1:27). Manusia sebagai makluk ciptaan Allah, tidak punya hak untuk mengubah kodratnya.

Kalau melihat fenomena sekarang ini, masalah penyimpangan seksual sudah tidak asing lagi seperti homoseksual yaitu hubungan seks dengan sesama jenis, sodomi yaitu hubungan seks melalui anus, pedofilia hubungan seks dengan anak-anak dibawah umur, sadisme seksual yaitu hubungan seks disertai dengan kekerasan, transeksual orang yang merasa belawanan jenis dari dirinya, dan masih banyak lagi penyimpangan seksual yang lainnya. Masalah penyimpangan yang demikian sangat meresahkan masyarakat, banyak korban sudah berjatuhan akibat dari penyimpangan yang demikian.

Transeksual adalah salah satu penyimpangan seksual yang sering dibicarakan baik dalam acara TV maupun dalam media yang lain. Bahkan transeksual dijadikan sarana hiburan oleh salah satu stasiun tv di Indonesia. Keberadaan kaum transeksual, tidak dapat dipungkiri hadir di tengahtengah masyarakat bahkan mungkin di dalam gereja. "ada pasangan transeksual yang hidup normal layaknya manusia pada umumnya, seperti menikah punya anak dan sebagainya dari data itu tidak disebutkan bagaimana ia punya anak." Seorang transeksual mempunyai keinginan untuk mengubah jenis kelaminnya. "Baru-baru ini dalam berita TV ONE" ditayangkan tentang wawancara terhadap kehidupan seorang yang transeksual yang sudah mengubah jenis kelaminnya. Dari hasil wawancara, seorang yang transeksual merasa bahwa mereka terjebak dalam tubuh lakilaki padahal jiwanya perempuan. Untuk itulah mereka melakukan operasi transeksual demi mengubah gender eksternalnya.

Fenomena operasi transeksual sudah tidak asing lagi. "Bahkan di beberapa negara seperti di Thailand yang mempunyai toleransi yang sangat tinggi bagi warganya, operasi transeksual bisa dilegalkan dengan alasan hak asasi seseorang." 3 Apalagi dengan berkembangan ilmu pengetahuan dan kemajuan teknologi saat ini. Seperti sudah tersedia dalam dunia medis yaitu pembedahan untuk mengubah jenis kelamin eksternal,

\footnotetext{
${ }^{1}$ Transeksual, diakses tanggal 21 Februari, 2010, terssedia di http://roll.co.id/index.php/forum.html?func=view\&id=1362\& \&atid=29,

${ }^{2}$ Transeksual, Siaran berita di TV ONE, tanggal 20 Februari 2010

${ }^{3}$ Kehidupan Transeksual di Thailand, Jelang Malam, tv one, selasa 13 juli 2010 pukul 00.30 wita
} 
memungkinkan seseorang yang ingin mengubah gender eksternal melakukan operasi transeksual.

Seorang transeksual berani mengambil resiko yaitu kegagalan operasi yang menyebabkan cacat fisik ("Kalau operasi gagal dan menembus usus besar ya kemungkinan buang air besar akan lewat vagina, kemudian bila nembus ke buli-buli, buang air kecil akan lewat vagina juga"). ${ }^{4}$ Operasi transeksual juga membutuhkan biaya yang tidak sedikit hanya untuk sekedar mendapatkan kenyamanan batin karena alasan kejiwaan.

Umumnya kaum transeksual menjalani operasi alat kelamin untuk mengubah gender sebagai sikap mempertahankan diri dari lingkungan sekitarnya. "Alasannya, mereka merasa tidak nyaman seperti kurang dihargai oleh lingkungannya. Faktor lainya untuk melakukan operasi transeksual, karena mereka sudah menjadi gay atau lesbi." ${ }^{5}$ Orang biasa pun tetap ada yang melakukannya karena mereka membenci alat kelamin yang menempel pada tubuhnya, misalnya payudara yang terlalu menonjol. Biasanya seorang pria akan menjalani operasi transeksual karena dia ingin dianggap sebagai dan dicintai sebagai seorang wanita. kebanyakan mereka yang melakukan operasi transeksual karena mereka tidak senang dengan dirinya, memandang dirinya tidak baik atau tubuhnya dianggap sebagai suatu kesalahan. Kebanyakan dari mereka berprofesi sebagai pekerja seks komersial. "Masyarakat dan aparat negara melekatkan streotipe dan stigma terhadap kaum lesbian, gay, biseksual dan transeksual sebagai orang dengan perilaku menyimpang dan sumber masalah sosial."

Sesuai dengan pendapat Kylem Yates dalam tafsiran Alkitab PL khususnya dalam (Kejadian 1:31), bahwa "Allah menciptakan manusia sempurna yaitu laki-laki dan perempuan Allah memandang itu sangat baik dalam ciptaan-Nya." ${ }^{7}$ seharusnya manusia sebagai ciptaan Allah memandang dirinya sudah baik dan tidak perlu mengubah dirinya menjadi lawan jenis dari dirinya. Tapi kenyataanya sebagian kecil manusia tidak senang dengan dirinya, sehingga harus mengubah dirinya menjadi lawan jenis dari dirinya. Firman Tuhan menjelaskan dalam (Kejadian 1:27), bahwa Allah hanya menciptakan dua jenis menusia laki-laki dan perempuan, bukan manusia setengah-setengah. Kalau melihat fakta di masyarakat sangat berbeda, bahkan mereka terang-terangan menunjukan identitas

\footnotetext{
${ }^{4}$ Diakses pada tanggal 19 juli 2010 tersedia di: http://news.okezone.com/read/2009/12/30/345/289431/nadia-menegaskan-status-diribertaruh-nyawa

${ }^{5}$ Hastening sakti, Mencari Kenyamanan Gender, diaakses tanggal 3maret 2010, tersedia di http://www.resep.web.id/seputar-sex/transeksual-mencari-kenyamanan-genderhtm

${ }^{6}$ Transeksual, diakses pada tanggal lmaret 2010 terdapat di http://www.detiknews.com/read/2009/11/01/125909/1232704/10/gabungan-lsm-mintapolisi-penyiksa-rico-dihukum

${ }^{7}$ Kylem Yates, Tafsiran Alkitab Wycliffe Volume 1 PL Kejadian Sampai Ester (Bandung: Gamdum Mas 2004), hal 30.
} 
mereka bahwa mereka adalah transeksual dan siap untuk operasi transeksual.

Ada beberapa konsep etika yang dapat membenarkan tindakan operasi transeksual, seperti etika teleologis yaitu sistem etika yang memperhatikan tujuan dari perbuatan itu atau hasil dari perbuatan itu. Baik tidaknya tindakan tersebut yang penting tujuanya baik, maka tindakan tersebut dapat dibenarkan, salah satunya seperti konsep Aristoteles yang menyatakan tujuan manusia adalah kebahagiaan." ${ }^{8}$ Demikian juga seseorang yang ingin operasi transeksual dalam melakukan tindakanya ada suatu tujuan yang ingin dicapainya yaitu sesuatu yang diangapnya baik bagi dia, yaitu kebahagiaan. Maka tindakan operasi transeksual bisa dibenarkan, karena bagi kaum transeksual, tindakan operasi transeksual bisa mendapatkan kebahagiaan. Banyak orang Kristen terjebak dengan sistem etika tersebut. Sistem etika tersebut paling masuk akal dan paling manusiawi, sehingga menyebabkan banyak orang Kristen memaklumi tindakan operasi transeksual. Sesuai dengan latar belakang masalah di atas, maka penulis ingin membahas tentang bagaimana etika Kristen memandang operasi transeksual dalam satu karya tulis yang berjudul "TINJAUAN ETIKA KRISTEN TERHADAP OPERASI TRANSEKSUAL".

\section{Pokok Masalah}

Berdasarkan latar belakang masalah di atas, maka penulis ingin membahas tentang: Bagaimana pandangan etika Kristen tentang operasi transeksual?

\section{Tujuan Penulisan}

Adapun tujuan penulisan dari pokok masalah diatas adalah: Untuk mengetahui pandangan etika Kristen tentang operasi transeksual

\section{Manfaat Penulisan}

Dalam penulisan penulisan ini, juga mempunyai beberapa harapan yang dapat diwujudkan sebagai maanfaat dari penulisan, sebagai berikut: Pertama, untuk dapat menemukan pandangan Etika Kristen tentang operasi transeksual. Kedua, Karya ilmiah ini diharapkan dapat menjadi bahan acuan bagi setiap orang percaya dalam pemahaman yang benar terhadap transeksual khususnya tentang bagaimana Etika Kristen memandang operasi transeksual. Ketiga , karya ilmiah ini diharapkan dapat berguna dalam pelayanan terhadap kaum transeksual.

\section{Batasan Penulisan}

${ }^{8}$ Aristoteles dalam Bertens, Etika (Jakarta: Gamedia Pustaka Utama, 1994), 242 
Mengingat begitu luasnya pembahasan tentang transeksual secara umum maka penulis membatasi karya ilmiah ini hanya berfokus pada operasi transeksual. Pembahasan operasi disini juga dibatasi hanya operasi alat kelamin ditinjau dari etika Kristen. Etika yang digunakan dalam penulisan ini dibatasi hanya etika yang bersifat deontologis.

\section{METODOLOGI PENELITIAN}

\section{Jenis Penelitian}

Dalam pembuatan karya ilmiah ini, penulis menggunakan jenis penelitian kualitatif, sesuai dengan masalah yang dibahas yaitu tentang pandangan etika Kristen terhadap operasi transeksual. Tujuan dalam penulisan yaitu mencari makna dari operasi transeksual ditinjau dari etika Kristen. Untuk mempermudah penulis dalam pembahasan karya ilmiah ini, penulis menggunakan pedomaman dari buku metodologi penelitian filsafat oleh Anton Bakker dan Achmad Charris Zubir, semua pembahasan ini terdapat dalam buku tersebut.

\section{Materi dan Sumber Penelitian}

Materi dan sumber penelitian adalah bahan-bahan atau sumbersumber penelitian yang digunakan penulis dalam menyelesaikan karya ilmiah ini. Adapun materi dan sumber penelitian yang dipakai penulis dalam karya ilmiah ini adalah sebagai berikut: Pertama, literatur tentang transeksual dan operasi transeksual, dan berbagai bahan dari internet untuk mempermudah penulis memahami apa itu transeksual faktor penyebabnya, dan mengapa seseorang mau melakukan operasi transeksual. Kedua, literatur tentang psikologi umum dan secara khusus psikologi abnormal, untuk memahami apa itu transeksual, operasi transeksual sebabsebab transeksual dan sebagainya. Ketiga, literatur tentang etika dasar, etika seksual dan lebih khusus etika Kristen, dengan mencari pandangan etika terhadap operasi transeksual. Keempat, Ensiklopedi umum dan ensiklopedi nasional Indonesia. Kelima, Alkitab dari berbagai versi dan Alkitab Penuntun.

\section{Teknik Pengumpulan Data}

Untuk memproleh data yang akurat dan tepat dalam penulisan karya ilmiah ini, dan juga dapat lebih memahami apa itu operasi transeksual dan tinjauan etika Kristen terhadap operasi transeksual penulis menggunakan teknik pengumpulan data yang meliputi:

\section{Inventarisasi}

Mengumpulkan bahan-bahan yang menyangkut literatur tentang etika, etika Kristen dan literatur yang menyangkut pembahasan tentang 
transeksual dan operasi transeksual yang dapat ditemukan dalam kepustakaan internet majalah dan tv, mengenai suatu konsep tersebut. Petama-tama menguraikan sebaik mungkin apa yang disajikan dalam literatur yang membahas transeksual dan operasi transeksual, dan menguraikan pandangan etika terhadap operasi transeksual. Ditentukan dengan tepat sejauh mana etika Kristen menilai transeksual.

\section{Evaluasi Kritis,}

Berdasarkan inventarisasi, atau bersama denganya, diberikan evaluasi mengenai masing-mansing, baik etika maupun operasi transeksual. Membahas serta menguraikan dengan cermat pandangan etika terhadap operasi transeksual melaluli data-data yang didapat serta masalah atau situasi yang lengkap.

\section{Sintesis}

Berdasarkan inventarisasi dan evaluasi kritis diusahakan membuat sintesis semua pemahaman, dengan mengitegrasikan ungsur yang baik.

\section{Teknik Analisis Data}

Tahap inti dalam penulisan karya lmiah, adalah analisis data yang sudah dikumpulkan oleh penulis. Teknik analisis data yang dipilih dalam pembahasan karya ilmiah sangat penting untuk mempermudah dalam penyelesaian dan mendapatkan hasil yang sesuai, tepat, benar dan akurat sesuai dengan harapan penulis dalam penulisan karya tulis ini. Adapun teknik analisis data yang digunaka oleh penulis adalah sebagai berikut.

\section{Interpretasi}

Interpretasi adalah cara penelitian dengan menggunakan metode penapsiran serta meninjau operasi transeksual dari segi etika kristen. Dengan cara interpretasi penulis berusaha memahami konsep dari berbagai teori etika dan menerapkan dalam etika Kristen yang menyangkut dengan operasi transeksual. Penulis juga berusaha menangkap arti dari konsep etika yang ada. "Penulis secara khusus akan menggunakan teori deontologis untuk membahas operasi transeksual, karena etika Kristen bersifat deontologis." 9

\section{ANALISIS AKHIR DAN PEMBAHASAN}

\section{Pandangan Alkitab Tentang Seksualitas \\ Tubuh}

\section{Baik}

Alkitab memberi penjelasan bahwa tubuh yang diciptakan Allah itu baik. Allah menciptakan tubuh Adam dari tanah, kemudian dari tulang

${ }^{9}$ Norman L. Geisler, Etika Kristen Pilihan dan Isu (Malang: Literatur SAAT, 2003), 26 
rusuk Adam diciptakanyalah Hawa, (Kejadian 2:7). Allah peduli atas tubuh manusia dengan menciptaan alam semesta yang baik dan lingkungan yang cukup bagi manusia. Yesus Kristus memiliki tubuh fisik,(Kolose 2:9). Jelas dari penjelasan ayat tersebut mengatakan bahwa tubuh yang baik adalah tubuh yang diciptakan Allah untuk kemuliaan-Nya.

\section{Dikutuk}

Salah satu akibat kejatuhan manusia pertama dalam dosa adalah tubuh dikutuk. (Kejadian3:16-19). Pemberontakan manusia menyebabkan turun murka Allah, (Rom. 1:18-19). Bekerja, melahirkan, dan kegiatan lain dibuat menjadi sulit karena kutukan-Nya. Tubuh benar-benar mengalami proses ketidaksempurnaan, dan pada akhirnya, mereka mati. "Pada mulanya manusia sempurna, namun sekarang manusia secara genetik menderita serta gen manusia mengalami perubahan. Segala macam penyakit seperti Diabetes dan penyakit lainnya adalah hasil dari pemberontakan manusia." Ini adalah akibat dari kutukan Tuhan karena ketidaktaatan manusia. George C. Scipione menjelaskan "Kegagalan genetik tubuh mengakibatkan masalah yang mempengaruhi seksualitas." bisa datang dalam langit baru dan bumi baru, (Roma 8:18-25).

\section{Seks}

Baik

Manusia dalam pandangan Allah itu sungguh amat baik, manusia dianggap ciptaan mulia agung dan suci. "Tuhan mempunyai rencana ketika ia menciptakan organ tubuh tersebut. Dengan demikian Tuhan mempunyai tujuan ketika Tuhan menjadikan seks itu bagi manusia."12 Seks yang diciptakan Allah itu suci dan mulia, itu tertulis dalam tulisan Paulus (1Timotius 4:4-5). Selain itu seks juga adalah bagian tubuh yang diciptakan Allah dan dikuduskan. Seks bukanlah sesuatu yang kotor dan jahat, seks itu baik karena Allah menciptakan seks, tidak ada yang tidak baik yang diciptakan Allah termasuk seks. Seperti yang dijelaskan dalam kitab Kejadian, "Beranak cuculah dan bertambah banyak agar memenuhi bumi dan berkuasa atasnya" (Kejadian 1:28) hal ini berati bahwa seks dalam pernikahan merupakan anjuran Allah kepada manusia untuk memenuhi maksud dan rencana Allah bagi dunia ini.

Dikutuk

Seks hanya dapat dibenarkan dalam hubungan suami istri atau dalam ikatan pernikahan, firman Tuhan mengatakan "ranjang pengantin harus dihormati" (Ibrani 13: 4). Pernyataan ini membenarkan bahwa seks hanya dapat dibenarkan kalau dalam ikatan pernikahan. Seks kalau dilakukan diluar pernikahan itu merupakan perzinahan. Zinah merupakan perilaku

\footnotetext{
${ }^{10}$ George C. Scipione, The Biblical View Of The Body, diakses pada tanggal 7 april 2010 di www.ipdx.org/index.html

${ }^{11}$ Ibid

${ }^{12}$ Tulus Tu’u, Etika dan Pendidikan Seksual (Bandung : Kalam Hidup, 1988), 11
} 
yang sesat sama dengan penyembahan berhala (1 Kor 6:9b-10). Paulus menentang dan melarang dengan keras praktek-pratek zinah, perilaku ini merupakan suatu tindakan yang berdosa yang tidak sesuai dengan ketetapan Allah.

Dosa sudah membawa dampak yang sangat besar dalam dunia ini, termasuk seks. Mulanya seks diciptakan untuk maksud dan tujuan yang mulia sesuai dengan maksud dan tujuan Allah, namun sekarang seks sudah disalahgunakan hanya sebagai pemuas nafsu belaka. Sekarang banyak menggunakan seks sebagai alat untuk mendapatkan uang. Disamping itu banyak penyimpangan seks yang berkembang, sekarang ini seperti homoseksual, biseksual dan yang banyak dibicarakan sekarang adalah transeksual yang berujung pada operasi transeksual. Fenomena ini dapat digambarkan bentuk dari akibat kejatuhan manusia kedalam dosa.

\section{Jenis Kelamin}

Baik

Manusia adalah unik dalam penciptaan, dia berdiri sendiri sebagai gambar Allah, (Kejadian 1:26-27). Tuhan menciptakan manusia menurut gambaran-Nya. Gambar adalah riasan, inilah yang membuat manusia berbeda dengan binatang dalam hubungan dengan Sang Pencipta.

Manusia bukanlah bentuk yang lebih tinggi dari kehidupan binatang. Manusia adalah berbeda. Hal ini berlaku sejak saat ia diciptakan (Kejadian 2:7). Tuhan menciptakan manusia laki-laki dan perempuan. Sementara beberapa aspek fisiologis jenis kelamin manusia mirip dengan hewan atau identik dengan seksualitas. Jenis kelamin manusia dan seksualitas tidak sama, Adam tidak bisa menemukan seorang penolong dan pasangan yang cocok untuk dia, kemudian Tuhan membuat Hawa (Kejadian 2:18-20). Kedua fakta menunjukkan bahwa manusia berkaitan dengan jenis kelamin untuk saling melengkapi dan bereproduksi. Verkuyl menjelaskan "Allah menjadikan manusia dalam jenis kelamin yang berbeda supaya dapat saling menolong dan saling melengkapi."

Persahabatan di dalam tugas yang diberikan manusia untuk memelihara ciptaan Allah adalah fokus dari jenis kelamin seksual manusia. Dengan demikian, ini adalah bagian dari identitas dasar manusia. Menjadi seorang pria atau wanita adalah hal yang baik, pada kenyataannya, sangat baik,( Kejadian 1:31)

\section{Dikutuk}

Dosa membuka perasaan bersalah dan rasa malu di hadapan Allah ,(Kejadian 3:8-10,21). Sebelum Allah mengutuki manusia dan alam semesta, Allah berkata bahwa akan ada pelecehan dan konflik dalam laki-laki dan perempuan, hubungan suami-istri, (Kejadian 3:16). Kebingungan, ketidaknyamanan, dan ketidaksesuaian ada di mana harmoni memerintah.

${ }^{13}$ J. Verkuyl, Etika Seksual (Jakarta: Badan Penerbit Kristen, 1963), 13 
"Kebingungan tentang gender dan peran gender menjadi norma." ${ }^{14}$ Kebingungan jenis kelamin adalah bagian dari hukuman Tuhan, (Roma. 1:18-32). Maka dapat dikatakan jenis kelamin juga dikutuk.

\section{Kepuasan Seksual}

Baik

"Perintah ini diberikan sebelum dosa masuk ke dalam dunia, oleh sebab itu persetubuhan dan prokreasi telah ditetapkan Allah dan dinikmati oleh manusia ketika ia masih dalam mula-mula yakni sebelum manusia jatuh. " 15 Perkawinan bukan sekedar ikatan antara dua insan yang memilih utuk hidup bersama dalam suka dan duka, tapi lebih dari itu yang meliputi serikat pekerja dan kepuasan seksual. Kepuasan seksual dapat meningkatkan hubungan antara suami dan istri. Alkitab menjelaskan bahwa kepuasan seksual dibenarkan jika kepuasan seksual direalisasikan antara satu laki-laki dan satu perempuan dalam ikatan pernikahan. (Ibrani 13:4)

\section{Dikutuk}

Allah melarang homoseksualitas dan kebinatangan. Ini membuktikan kepuasan seksual telah menyimpang. Kenyataan bahwa banyak orang menyalurkan hasrat seksual mereka secara langsung terhadap orang atau benda lain selain pasangan mereka, dan tidak mengontrol keinginankeinginan ini adalah bukti kebejatan manusia. "Kebejatan ini merupakan bagian dari proses Allah memberikan mereka atas keinginan jahat mereka, (Roma. 1:18-32.) Karena ini adalah bagian dari penghakiman Allah terhadap memberontakan dan penyembahan berhala." ${ }^{\text {,16 }}$

Dunia menganggap Seks sebagai pemuas nafsu semata, sehingga menghalalkan segala cara untuk mencari kepuasan seks termasuk hal-hal yang sangat dilarang oleh Tuhan. "para pencari kenikmatan memperlakukan seks sebagai alat untuk memuaskan napsunya." ${ }^{\text {"7 }}$

\section{Dampak Dosa}

Dampak kejatuhan manusia ke dalam dosa membawa akibat buruk bukan saja bagi manusia itu sendiri tetapi juga berakibat terhadap alam. Alkitab sangat jelas menggambarkan akibat kejatuhan manusia kedalam dosa. Disini penulis hanya akan membahas yang menyangkut tentang transeksual

(Roma pasal 1, 2 dan Korintus 6) jelas membuktikan bahwa pola-pola kepuasan seksual harus dipelajari, contohnya Homoseksualitas dan

\footnotetext{
${ }^{14}$ Ibid

15 Tim Bverly Lahaye, Kesidupan Seks dalam Pernikahan (Bandung: kalam Hidup, dan ANDI, 1976), 11

${ }^{16}$ The Effects of Sin on Sexuality, diakses pada tanggal 7 april 2010 terseduia di www.ipdx.org/index.html

${ }^{17}$ Tulus Tu'u, Etika dan Pendidikan Seksual (bandung : Kalam Hidup, 1988)
} 
transeksual. "(Roma 1) berbicara tentang meninggalkan fungsi alami kepada tidak alami. Alkitab menjelaskan mereka bisa dipisahkan, dan dibenarkan oleh darah Yesus dan kuasa Roh Kudus, Yesus mengapuni orang, cabul dan pezinah dimasukkan dalam daftar orang-orang berdosa yang bertobat." 18

Dapat disimpulkan bahwa kelainan seksual, adalah belajar pola berpikir, menginginkan, dan bertindak. Setiap orang berdosa mengembangkan nya. Dampak dosa ini adalah pemberontakan terhadap Allah, pemberontakan terhadap apa yang sudah ditetapkan oleh Allah, dan godaan untuk menjadi seperti Allah. "Manusia ingin mengendalikan nasibnya daripada terus didalam kesetiaan terhadap hukum Allah. Oleh karena itu manusia menginginkan definisi mutlak dan arah kendali atas tubuhnya, jenis kelamin seksual, dan kepuasan seksual."19

\section{Penebusan Yesus}

Kedatangan Yesus dalam dunia dan pengorbanan-Nya di kayu salib membawa harapan bagi manusia yang sudah jatuh kedalam dosa. Pengorbananya di kayu salib memberi pemulihan bagi manusia yang berdosa, bukan saja dosa yang diampuni, tetapi juga seluruh aspek kehidupan manusia termasuk dalam hal seksual, yang didalamnya juga terdapat transeksual.

\section{Tubuh Ditebus}

Jika inkarnasi dari Yesus membuktikan bahwa tubuh yang baik dan tidak jahat, maka kebangkitan-Nya menunjukkan bahwa tubuh adalah ditebus. Kebangkitan adalah bagian keseluruhan dari keselamatan-Nya dari dosa.

\section{Jenis Kelamin Ditebus}

"Yesus dalam pengorbanan-Nya menebus dalam segala aspek kehidupan manusia termasuk jenis kelamin Paulus mengajarkan tentang tradisi gereja dalam (1 Korintus 11:2-16.12). Dia berpendapat bahwa penebusan Kristus memiliki implikasi bagi hubungan perempuan lakilaki." 20 Didalam Tuhan, laki-laki dan perempuan tidak merdeka tetapi saling tergantung. Oleh karena itu, karya Kristus menebus dan melindungi perkawinan dan perbedaan perannya dari pelecehan. Kuasa-Nya dan syafaat-Nya menjamin bahwa setiap kutukan dan kebingungan tentang gender dan peran seksual dapat diatasi di dalam Dia.

\section{Tinjauan Etika Kristen Tentang Operasi Transeksual}

Etika Kristen yang digunakan dalam analisis akhir pembuatan karya tulis ini adalah etika Kristen yang bersifat deontologis, yaitu etika yang

\footnotetext{
${ }^{18}$ The Effects of Sin on Sexuality, diakses pada tanggal 7 april 2010 tersedia di www.ipdx.org/index.html

${ }^{19}$ Ibid

${ }^{20}$ The Effects of Sin on Sexuality, diakses pada tanggal 7 april 2010 tersedia di www.ipdx.org/index.html
} 
berpusat kepada kewajiban atau etika yang berdasarkan aturan yang ditetapkan. "Etika Kristen bersifat deontologis karena etika Kristen didasarkan pada perintah-perintah Allah, dan wahyu Allah di dalam Alkitab." ${ }^{21}$ Etika Kristen berpedoman pada Firman Allah dalam setiap pengambilan keputusan etis.

Firman Allah menjadi pedoman dalam pembahasan masalah transeksual ditijau dari etika Kristen. Disini penulis akan membahas beberapa hal yang menyangkut tentang operasi transeksual antara lain sebagai berikut:

\section{Mutilasi atau Modifikasi Tubuh}

Tinjauan Alkitab tentang kerusakan pada tubuh dan yang lebih buruk mutilasi disengaja sebagai sebuah penghinaan yang sangat besar. Paulus mengajarkan bahwa tubuh adalah bait Roh Kudus dan harus dilindungi, (1 Korintus. 6:12-20). "Manipulasi hormonal yang ekstrim dan bedah mutilasi yang terlibat dalam operasi transeksual tidak dibenarkan kecuali kasus tersebut menyangkut kesehatan sedang dipertaruhkan." ${ }^{22}$ Seharusnya seorang tidak boleh merubah gender yang sudah ditentukan oleh Allah.

Operasi transeksual secara bebas dilakukan karena masalah psikologis seseorang. Dengan demikian akan memberi peluang bagi tindakan yang lain yang melanggar kaidah yang sudah ditetapkan untuk tidak dilakukan seperti, aborsi dengan alasan menjaga bentuk tubuh ibu. Oleh karena itu tidak dibenarkan menentukan jenis kelamin seseorang melalui operasi transeksual, meskipun pikiran mereka tidak dapat menerima tubuhnya.

Seorang pria sejak lahir secara anatomi adalah seorang laki-laki, karena merasa terjebak dalam tubuh perempuan, dia mau beralih fungsi menjadi perempuan, dengan cara berusaha merubah tubuhnya semirip mungkin dengan lawan jenisnya yaitu perempuan." 23 Dengan berbagai cara baik melalui operasi perubahan anatomi tubuh maupun dengan pemakaian hormon perempuan, berharap menjadi semirip mungkin dengan lawan jenisnya. Tindakan ini disebut dengan pembalikan gender seksual. Maka dapat dikatakan tindakan ini menyalahgunakan pemberian Tuhan yang baik.

Operasi lahiriah seorang transeksual untuk menjadikan tubuh lebih dekat dengan apa yang ada dalam pikiran itu merupakan sebuah kekejian bagi Allah. "Seorang wanita tidak boleh mengenakan pakaian laki-laki, dan seorang laki-laki tidak boleh mengenakan pakaian wanita, bagi siapa saja

\footnotetext{
${ }^{21}$ Norman L. Geisler, Etika Kristen Pilihan dan Isu, (malang: Literatur SAAT, 2003), 26

${ }^{22}$ George C. Scipione, The Biblical View Of The Body diakses pada tanggal 7 april 2010 di www.ipdx.org/index.html

${ }^{23}$ Gerald c Davison ,John M. naele, \& Ann m. Kring, Psikologi Abnormal Edisi 9 (Jakarta: Rajawali pers), 612
} 
yang melakukan hal-hal ini adalah kekejian bagi TUHAN, Allahmu" (Ulangan 22:5). Dalam hal berpakaianpun jika tidak menjadi berkat malahan menjadi batu sandungan itu merupakan kekejian bagi Allah. Jika banci sangat menjijikan bagi Allah maka bedah radikal transeksual untuk mengubah jenis kelamin luar adalah jauh lebih buruk. Menghalalkan operasi transeksual untuk memulihkan penderita psikologis ini seharusnya tidak pernah terjadi. Jika dosa kecil seperti banci adalah kekejian bagi Allah, maka operasi traseksual harus super kekejian. Sebagai orang percaya yang hidup di dalam kasih Kristus dan taat akan Firman Allah seharusnya tidak mendukung operasi transeksual maupun perusahaan-perusahaan yang melakukanya.

Operasi Transeksual Bertentangan dengan Maksud dari Seksualitas

Pembalikan gender seksual dan memprakarsai apa yang sudah Tuhan berikan melalui bedah operasi alat kelamin dan modifikasi tubuh untuk mengubah alat kelamin luar menjadi semirip mungkin dengan lawan jenisnya, sangat bertentangan dengan maksud dari seksualitas tersebut. Alkitab mengatakan Allah menciptakan seseorang sebagai laki-laki dan sebagai perempuan mempunyai maksud dan tujuan seksualitas, adapun maksud dan tujuan dari seksualitas antara lain:

\section{Mendapatkan Keturunan}

Alkitab perjanjian lama tepatnya kitab Kejadian menyatakan bahwa manusia diperintahkan Allah untuk bereproduksi, beranak cucu untuk memenuhi bumi, (Kejadian 1:26-28). Manusia untuk mendapakan keturunan secara normal, harus melalui hubungan seksual atau hubungan intim antara laki-laki dengan perempuan. Hubungan seksual yang dikehendaki Allah adalah hubungan dalam ikatan perkawinan.

Seorang yang sudah melakukan operasi transeksual tidak mungkin mendapakan keturunan secara normal, meskipun alat kelamin luar yang merupakan bagian alat reproduksi pada manusia bisa diubah. Misalnya seorang laki-laki mengubah jenis kelaminnya menjadi perempuan, melalui bedah transeksual, masih ada bagian alat repropduksi lain yang terdapat pada manusia yang sampai saat ini belum bisa diubah atau ditambahkan, seperti indung telur sebagai penghasil sel telur, rahim sebagai tempat pertumbuhan janin, dan testis sebagai penghasil seperma. Maka dari itu, seseorang yang sudah melakukan operasi transeksual tidak mungkin lagi bisa punya anak. Dengan demikian bertentangan dengan maksud dari seksualitas yaitu punya anak.

\section{Hubungan Heteroseksual}

Hubungan seksual atau hubungan intim pada mulanya dan umumnya Allah hanya menciptakan hubungan yang heteroseksual, yaitu hubungan antara laki-laki dengan perempuan. Sebab itu seorang laki-laki akan meninggalkan ayahnya dan ibunya dan bersatu dengan istrinya sehingga keduanya menjadi satu daging (Kejadian 2:24) ayat ini menjelaskan bukan 
hubungan homoseksual tapi heteroseksual. Mirip seperti yang disebutkan di (Efesus 5:22-33) yang hanya membahas konteks hubungan heteroseks dimana kasih Kristus adalah dasar hidup suami istri, tetapi tidak menjelaskan sesuatu diluar konteks seperti hubungan sesama jenis.

Seorang transeksual mempunyai hubungan antara sesama jenis yang disebut dengan homoseksual, meskipun mereka mengubah jenis kelamin luarnya. Karena sejak dilahirkan seseorang sudah dikodratkan dengan jenis kelamin yang sudah ada sejak lahir tampa perubahan. Mereka melakukan hubungan sesama jenis karena mereka berangapan bahwa mereka adalah lawan jenis dari dirinya sehingga pada umumnya mereka tidak mau dikatakan sebagai homoseksual.

Allah menginginkan dalam hubungan intim manusia hanya dibenarkan berhubungan intim antara laki-laki dengan perempuan. Hubungan seksual seorang yang sudah menjalani operasi transeksual sudah bertentangan dengan maksud dari seksualitas. Hubungan intim yang sesui dengan Firman Allah adalah hubungan heteroseksual antara laki-laki dengan perempuan dalam satu ikatan pernikahan.

\section{Homoseksual Bagi Transeksual}

Allah didalam wahyu-Nya (Alkitab) baik perjanjian lama maupun dalam perjanjian baru, sangat jelas tidak suka atau bahkan menentang perilaku homosksual. Dalam teks-teks perjanjian lama homoseksual dipandang secara negatif (Imamat 18:22; Kejadian 19). Demikian pula dalam teks-teks perjanjian baru memandang homoseksual sebagai suatu perilaku seksual yang menyimpang (Roma 1:26-27; 1 Korintus 6:9-11; 1 Timotius 1:10 dan Yudas 1:7). Perilaku homoseksual adalah tindakan yang sangat berdosa karena tindakan tersebut menentang apa yang sudah ditetapkan oleh Allah bahwa seksual seharusnya heteroseksual antara laki dan perempuan, bukan hubungan sesama jenis.

Dalam perilaku homoseksual hanya mencari kenikmatan semata, karena perilaku homoseksual menghalalkan behubungan dengan sesama jenis untuk mendapatkan kenikmatan semata. Perilaku homoseksual memiliki hubungan seks yang tidak wajar dan menyimpang dari seharusnya, seperti yang dikatakan oleh Robert dalam bukunya "bahwa hubungan seksualitas dengan cara homoseksualitas dipandang bagian dari penyimpangan hubungan perkawinan." ${ }^{24}$

"Terlepas dari anggapan bahwa seorang transeksual yang secara biologis normal, tetapi secara psikologis merasa terperangkap dalam tubuh yang berlawanan." 25 Perilaku seksualnya sudah tentu memiliki perilaku

\footnotetext{
${ }^{24}$ Robert P. Barrong. Etika Seksual Konteporel (Bandung: Ink Media, 2006), 79

${ }^{25}$ Gerald c Davison ,John M. naele, \&e Ann m. Kring, Psikologi Abnormal Edisi 9 (Jakarta: Rajawali pers), 612
} 
homoseksual meskipun sudah merubah gender secara anatomi. Seorang transeksual pada umumnya tidak menyukai lawan jenisnya karena dia merasa di dalam dirinya adalah lawan jenis dari apa yang terlihat. Memang seorang transeksual tidak mau diangap sebagai homoseksual meskipun mereka menyukai sesama jenis karena ia sendiri merasa memiliki gender atau jenis kelamin yang lain dari dirinya, tetapi secara umum bisa dilihat bahwa perilaku seksual yang dimiliki seorang transeksual adalah prilaku homoseksual, karana mereka menyukai sesama jenis kelamin, meskipun secara anatomi tubuhnya sudah diubah menjadi lawan jenisnya. Orang yang sudah menjalani operasi transeksual selalalu berakhir menjadi homoseksual terlepas dari semua perubahan anatomi seksualitas seseorang.

\section{Transeksual dan Operasi Transeksual}

"Maka Allah menciptakan manusia itu menurut gambar-Nya, menurut gambar Allah diciptakan-Nya dia; laki-laki dan perempuan diciptakan-Nya mereka. (Kejadian 1:27)

"Ada orang yang tidak dapat kawin karena ia memang lahir demikian dari rahim ibunya, dan ada orang yang dijadikan demikian oleh orang lain, dan ada orang yang membuat dirinya demikian karena kemauannya sendiri oleh karena Kerajaan Sorga. Siapa yang dapat mengerti hendaklah ia mengerti." (Matius 19:12)

Bagaimanakah Orang Kristen memahami seorang transeksual? Menurut Kitab Kejadian, TUHAN hanya membuat dua jenis manusia yaitu laki-laki dan perempuan. Tidak ada separuh laki-laki atau separuh perempuan. Kristus Yesus menyebut ada orang yang tidak dapat kawin (menikah) karena sudah dari rahim ibunya. Artinya, Kristus Yesus telah memiliki pandangan yang jauh, bahwa ada orang yang mengalami distorsi seks sehingga tidak dapat melakukan pernikahan yang sebenarnya antara laki-laki dan perempuan. Perlu memahaminya, di dalam golongan ini, terdapat kelompok transeksual tersebut.

"Faktor-faktor biologis seperti cacat kromoson, dan kelainan gen, dan juga faktor psikoseksual yang dialami bisa menyebabkan seseorang menjadi transeksual atau waria, sehingga menyulitkan penderita hidup sesuai dengan jenis kelamin yang ada." ${ }^{26}$ Alkitab tetap tidak memperkenankan prilaku homoseksual terlebih lagi tindakan operasi transeksual, karena tubuh adalah bait Roh Kudus dan juga tubuh untuk kemuliaan Tuhan, bukan untuk nafsu belaka (1Korintus 6:12-20). Sebagai orang percaya kita tidak punya hak untuk mempermainkan tubuh. Paulus dalam tulisanya menekankan bahwa dalam kehidupan kita, apapun yang diperbuat harus perbuatan yang membangun, dan juga perlu mementingkan orang lain (1Korintus 10:23-24).

${ }^{26}$ Supratiknya, Mengenal Prilaku Abnormal (Yogyakarta: Kanisius 1995), 25 
Transeksual bisa dikatakan sebagai gejala alamiah yang bisa terjadi dari proses kejadian (kelahiran) manusia, dan Kristus Yesus memaklumi hal itu." $^{27}$ (Matius 19:12) memberi pemahaman bahwa seorang transeksual tidak bisa menikah, Alkitab tetap tidak membenarkan pada perilaku penyimpangan seksual yang dilakukan (seks antara transeksual dan lakilaki, tentunya), dan juga tindakan operasi transeksual tidak diperkenankan untuk dilakukan. Sebagai orang yang sudah terlahir dengan perilaku abnormal seperti kasus transeksual, tetap harus hidup sesuai dengan Firman Tuhan disamping berusaha untuk merubah keadaanya, seandainya tidak bisa merubah keadaanya, itu juga bukan dosa, hasalkan tidak melanggar hukum-hukum Allah. Seorang transeksual harus juga berusaha mengerti dan memahami kehendak Allah sebab siapa yang mau terlahir dengan keadaan abnormal demikian.

\section{Sikap Orang Kristiani Terhadap Kaum Transeksual Menerima Seorang Transeksual Sebagai Bagian Tubuh Kristus}

Selama ini kaum transeksual masih dipandang sebagai kaum yang menyimpang dan perlu dijauhi. Masyarakat secara keseluruhan belum bisa menerima dan hidup bersama kaum transeksual ini.

Orang kristen sudah selayaknya tidak melakukan penilaian negatif terhadap kaum transeksual atau waria. Yesus sudah menjadi teladan yang baik, dengan mengasihi orang berdosa dan tetap membenci dosanya. Orang percaya mengasihi orang yang demikian bukan menjauhinya meskipun demikian kita tetap tegas terhadap dosanya. Kita sebagai orang percaya mungkin dapat mendukung agar mereka merasa yakin akan potensi dirinya, dan kalau bisa memberi dukungan agar hidup kudus di tengah kesadaran dirinya yang merasa bimbang akan jenis kelaminnya.

Sebenarnya dengan "kekurangannya" itu mereka punya potensi lebih besar untuk terhindar dari skandal seksual seperti percabulan. Mereka akan punya lebih banyak waktu untuk beribadah dan melayani Tuhan. Gereja juga bisa memberikan pelayanan kepada mereka seperti melayani kaum transeksual atau menjadi penginjil transeksual.

\section{Menolong Seorang Transeksual Untuk Pemulihan}

Orang yang percaya juga harus menolong jangan sampai mereka terjerumus pada dosa apalagi sampai melakukan operasi transeksual. Ada beberapa hal yang bisa dilakukan untuk menolng mereka untuk proses pemulihan.

Pertama, bergaul dengan mereka. Kita bisa mengetahui latar belakng kehidupanya, sehingga kita bisa menolong mereka sesuai dengan latar belakang masalahnya. Bergaul dengan mereka membuat mereka percaya

\footnotetext{
${ }^{27}$ Dedyriyadi, Bagaimana Memehami Waria, Diakses pada tanggal 27 mei 2010 tersedia di. http://sosbud.kompasiana.com/2010/05/05/bagaimana-memahami-waria/
} 
kepada kita sehingga kita bisa mengarahkan dia kearah yang lebih positif seperti ke gereja, seminar pemulihan, dan mendorong untuk ikut konseling pribadi sehingga ia bisa pulih dari keadaanya.

Kedua, terbuka terhadap mereka. Keterbukaan kita terhadap mereka adalah kunci dimana mereka mau terbuka terhadap kita. Keterbukaan kita terhadap mereka bisa membuat mereka diterima dan mau terbuka, dam mencurahkan isi hatinya dan bebannya kepada kita sehingga mereka merasa bebas dari bebanya.

Ketiga, mendengarkan. Mendengarkan adalah cara terbaik supaya mereka merasa diterima dan merasa diperhatikan. Kalau mereka sudah merasa diterima mereka akan lebih terbuka sehingga pemulihanya bisa lebih cepat.

Segala segala tindakan mungkin harus dilakukan untuk membantu orang berasumsi sebagai gender yang berbeda.

\section{Bagi yang Sudah Menjalani Operasi Transeksual}

Bagi orang yang sudah melakukan operasi transeksual dan bertobat akan ada bekas luka harfiah yang sulit dihilangkan. Total restorasi atau total pemulihan adalah mustahil, maka diperlukan beberapa penanganan:

Pertama, Konseling tentang identitas di dalam Kristus dan peran gender. Konseling adalah "hubungan timbal balik antara dua induvidu, yaitu konselor yang berusaha menolong atau membibing dan konsele yang membutuhkan bimbingan untuk mengatasi persoalan yang dihadapi." ${ }^{28}$ Konseling ini akan menolong mereka menerima dirinya dan menghilangkan rasa bersalah. Konseling ini akan sangat diperlukan untuk membantu orang yang demikian dalam proses pemulihannya.

Kedua, Gereja harus merangkul orang semacam itu sehingga setan tidak dapat membinasakan dia dengan keputusasaan, (1 Korintus. 2:5-11.)

\section{Pembinaan Secara Rohani}

Pendidikan rohani merupakan senjata yang ampuh dalam menangkis berbagai serangan iblis dalam mempengaruhi perkembangan anak. Keluarga dan gereja harus memahami pentingnya pembinaan secara rohani. Ada beberapa hal yang bisa dilakukan dalam pembinaan secara rohani:

\section{Pendidikan Rohani dalam Keluarga}

Orang tua adalah pihak yang paling bertanggung dalam memenuhi kebutuhan rohani anak. Memenuhi kebutuhan rohani seorang anak berati sudah membentengi si anak dari berbagai pengaruh dunia ini. Orang tua harus dapat memberi nilai-nilai yang kekal kepada anak-anaknya yaitu dengan memperkenalkan Kristus sebagai jalan keselamatan satu-satunya, berkumpul bersama untuk berdoa, henghafal ayat firman Tuhan dan beribadah singkat.

${ }^{28}$ Gary R. Collins, Konsoling Kristen yang Efektif (Malang, SAAT, 1990), 3 


\section{Pembinaan oleh Gereja}

Gereja mempunyai tanggung jawab dalam pemenuhan kerohanian jemaat, hubungan yang itim dengan Tuhan dapat mengakibatkan perilaku yang takut akan Tuhan dan mentaati perintah-Nya. Gereja seharusnya tidak lepas tanggung jawab jika jemaatnya mengalami masalah sebaliknya merangkul mereka dan mendorong mereka untuk bertobat dan lebih dekat kepada Tuhan. Ada beberapa hal yang bisa dilakukan oleh gereja:

\section{Retreat}

Retreat sangat membantu jemaat dalam pemulihan rohani nya. Kadang jemaat merasa kering dalam hal rohani atau merasa hampa maka dari itu dengan diadakanya retreat kerohanian jemaat dapat terbakar kembali untuk mengikuti Tuhan dan melayani Tuhan. Ada beberapa macam retreat yang bisa dilakukan: Pertama retreat kaum bapak, kedua retreat kaum ibu, ketiga retreat pemuda, keempat retreat sekolah minggu, dan kelima retreat seluruh keluarga.

\section{Seminar}

Gereja perlu mendorong jemaatnya untuk mengikuti seminar rohani yang berkaitan dengan masalah seksualitas dan dan peranan gender. Seminar yang bisa dilakukan antara lain seminar laki-laki sejati untuk kaum pria dan seminar wanita bijak untuk kaum wanita, bisa juga mengikuti seminar yang lain. Jika memungkinkan gereja juga bisa juga mengadakan seminar sendiri baik untuk kaum bapak maupun untuk kaum wanita dengan mengundang pembicara yang berkaitan.

\section{Peranan Keluarga dalam Pencegahan Ganguan Identitas Gender} Pembinaan dalam Keluarga

Faktor utama terjadinya ganguan identitas gender adalah faktor keluarga dan lingkungan. Peran keluarga dalam perkembangan mental seseorang sangat penting. Pengaruh pendidikan yang didapatkan oleh seorang anak pada waktu kecil akan sangat berpengaruh terhadap ingatan dan kepribadian si anak, oleh karena itu apa yang dilakukan oleh keluarga sebenarnya menjadi sarana pencegah sejak dini dimana anak-anak dapat memahami peran mereka sebagai gender yang sudah ditetapkan. Alex Sobur dalam bukunya mengatakan "Mendidik anak adalah tugas yang paling mulia yang pernah diamanatkan Tuhan kepada orang tua." 29 Tentu dalam hal ini keluarga mempunyai tanggung jawab yang besar dalam pertumbuhan sang anak, bukan saja secara fisik bertumbuh tetapi juga secara mental juga bertumbuh dengan baik.

\section{Pendidikan Seks dan Peran Gender Sejak Dini}

Orang tua dituntut memiliki kepekaan, keterampilan, dan pemahaman agar mampu memberi informasi dalam porsi tertentu, yang

${ }^{29}$ Alex Sobur, Pembinaan Anak Dalam Keluarga (jakarta: BPK Gunung Mulia, 1988), 1 
justru tidak membuat anak semakin bingung atau penasaran. Orang tua adalah pihak yang paling bertanggung jawab terhadap anak dalam masalah pendidikan, termasuk pendidikan seks. Pendidikan seks sejak dini membuat anak mengetahui dan memahami apa arti seks yang sebenarnya.

Pendidikan seks dan peran gender merupakan bagian penting dari pendidikan dasar, akhlak, dan ibadah. Terlepasnya pendidikan seks dan peran gender dengan ketiga unsur itu akan menyebabkan ketidakjelasan arah dari pendidikan seks itu sendiri. Seperti yang dikatakan oleh Staton dalam bukunya "pembentukan akhir dari identitas anak sebagai anak lakilaki atau perempuan pada umumnya terjadi sebelum usia lima tahun. Antara usia tiga dan lima tahun, anak-anak mengalami rasa ingin tahu yang sangat besar dan melakukan identifikasi yang mendalam sehubungan dengan masalah jenis kelamin.. ${ }^{30}$ Oleh karena itu, dibutuhkan usaha untuk memuaskan rasa ingin tahu anak tentang seks dengan bersikap terbuka dan menjalin komunikasi yang efektif dengan mereka yang tentunya sesuai dengan kapasitas usia dan intelektualnya. Tetapi kebanyakan orang tua tidak memahami pentinya pendidikan seks dan peran gender pada anak. Tidak jarang orang tua masih menanamkan persepsi yang negatif, yaitu seks (termasuk pengenalan fungsi kelamin) itu jorok, porno, dan tabu untuk dibicarakan. Ada kalanya orang tua memberikan pendidikan seks yang salah kepada anaknya seperti mengenakan pakaian perempuan kepada anak laki-lakinya, ini akan sangat berpengaruh dalam kehidupanya ketika dia dewasa yang menyebabkan ada konflik antara anatomi seks dan identitas gender.

Orang tua seyogyanya tidak menunggu sampai anak mencapai usia belasan tahun untuk berbicara tentang masalah seksual, anak-anak harus sudah mengetahui perubahan dan perkembangan yang akan terjadi di masa remaja dan seterusnya terkait seksualitasnya pada masa sebelumnya secara wajar.

\section{Pola Asuh yang Benar}

Pola asuh orang tua terhadap anak juga berperan dalam perkembangan mental anak, maka dari itu dalam mendidik anak orang tua harus menggunakan pola asuh yang benar seperti: Pertama menjadi teladan. Seorang anak akan mengukiti apa yang dilakukan orang tuanya daripada apa yang diucapkanya. Jika orang tua menginginkan anaknya mengikuti apa yang baik, jadilah teladan yang baik dengan melakukanlah yang baik dalam keluarga. Kedua, memberi dukungan pada anak. Seorang anak laki-laki harus mendapatkan dukungan dari ayahnya supaya dia dapat menghargai pria. Soekahar mengatakan dalam bukunya "Jikalau anak laki-laki tidak pernah mendapat dukungan moral dari ayah dalam perjalanan hidup

\footnotetext{
${ }^{30}$ Stanton L. \&rbrennaB. Jones, How and When To Tell Your Kids About Sex, Bagaimana dan Kapan Memberitahu Anak Anda Mengenai Seks, (Surabaya: Mementum 2004), 171
} 
anaknya untuk menjadi laki-laki, maka akan membuat anak laki-laki tersebut kehilangan penghargaan terhadap ayahnya, atau jenis kelaminya itu sendiri". ${ }^{31}$ Tidak adanya figur seorang ayah pada kasus anak laki-laki menyebabkan ia tidak mendapatkan model seorang pria. Ini akan berdampak kepada kebencian pria berujung pada transeksual. Demikian juga sebalikanya jika seorang anak perempuan tidak mendapat dukungan dari ibunya. Orang tua dalam keluarga harus mencerminkan sikap sebagai orang tua yang baik. Ketiga, menjalin hubungan yang harmonis dengan anak. Hubungan yang harmonis dengan anak akan menolong anak menjadi dewasa secara iman dan mental. Hubungan yang harmonis yang dimaksud adalah seperti yang dikatakan oleh Supraktiknya "tidak menelantarkan secara fisik, menujukan rasa cinta dan kasih sayang, memberikan penghargaan dan perhatian terhadap prestasi anak, menghukum secara wajar, tidak overproteksi, memberikan kepada anak untuk mengambil keputuhan sendiri, dan yang terakhir komonikasi yang efektif." 32 Dengan demikian anak akan menjadi anak yang baik kelak ketika ia dewasa dan hidup dalam kepastian tentang dirinya.

\section{PENUTUP}

\section{Kesimpulan}

Berdasarkan pembahasan yang telah dikemukakan oleh penulis dalam karya ilmiah ini maka penulis menyimpulkan. Pertama, tubuh, seks, jenis kelamin, dan kepuasan seksual, pada dasarnya diciptakan Allah sangat baik, mulia dan suci dan dengan tujuan yang baik, dan ini juga merupakan gambar Allah. Akibat kejatuhan manusia pertama kedalam dosa maka gambar Allah menjadi rusak, sehingga Tubuh, seks, jenis kelamin, kepuasan seksual kehilangan peranannya. Banyak penyimpangan seksual yang berkembangan saat ini, dan sudah sangat meresahkan di dalam masyarakat. Kedua, transeksual adalah salah satu bentuk kelainan seksualitas yang abnormal dimana seorang penderita mengalami ganguan identitas gender, yaitu seseorang merasa terjebak dalam tubuh yang berbeda. Ketiga, secara etika Kristen menjadi seorang transeksual atau waria tidak menjadi masalah. Karena secara Alkitabiah ada orang yang terlahir dengan keadaan abnormal. Perilaku homoseksual bagi seorang transeksual secara Alkitabiah dilarang karena melanggar prinsip Alkitab. Keempat, segala bentuk tindakan operasi transeksual yang mementingkan keegoisan dan Andi, 1987)

${ }^{31}$ H. Soekahar, Hooseksualitas Tijauan Singkat Bedasarkan Iman Kristen (Yogyakarta:

32 Supratiknya, Mengenal Prilaku Abnormal (Yogyakarta: Kanisius 1995), 28 
kenikmatan belaka dari segi etika Kristen adalah salah dan melanggar kaidah Tuhan yang sudah ditetapkan. Seorang yang melakukan operasi transeksual sudah menghina dan tidak menghargai dan juga tidak mengucap syukur atas apa yang sudah diberikan Tuhan yaitu kodrat sejak lahir sebagai laki-laki maupun perempuan. Seorang yang melakukan operasi transeksual akan mempunyai prilaku homoseksual. Kelima, orang kristiani harus dapat menampung dan menerima mereka sebagai bagian dari tubuh Kristus, mungkin Tuhan punya rencana bagi kaum transeksual yang rohani untuk menjadi penginjil kaum transeksual.

\section{Saran-Saran}

Fenomena operasi transeksual sudah ada sejak lama dan sudah tidak asing lagi ditengah-tengah masyarakat termasuk di kalangan orang percaya, untuk itu penulis memberikan saran-saran sebagai berikut: Pertama, orang percaya harus benar-benar telah dilahirkan baru didalam Kristus dan meninggalkan kehidupan lama dengan sungguh-sungguh. Kedua, faktor keluarga berperan sangat pital dalam perkembangan dan pertumbuhan mental anak-anak maka dari itu keluarga (orang tua) harus memberikan pendidikan yang benar kepada anak-anak termasuk pendidikan seks yang benar sesuai dengan Firman Tuhan. Orang tua juga harus menjadi teladan yang benar, bagaimana menjadi ayah dan ibu yang baik. Ketiga, gereja perlu memikirkan kehidupan kaum transeksual sebagai bagian dari tubuh Kristus dan gereja juga mengupayakan pembinaan bagi kaum transeksual supaya memahami panggilan mereka. Keempat, gereja, seharusnya tidak mengijinkan tindakan operasi transeksual yang melanggar hukum Allah. Kelima, pendidikan dalam keluarga sangat berperan dalam pembentukan moral si anak kelak, keluarga berkewajiban memberikan pendidikan yang layak dan benar kepada si anak, termasuk dalam kerohanian. Anggota Keluarga juga harus menjadi teladan yang baik bagi si anak. Keenam, gereja perlu memberikan pencerahan kepada anggota gereja bagaimana harus menghargai pemberian Tuhan termasuk jenis kelamin. Ketujuh, gereja harus terbuka serta menunjukan sikap belas kasihan terhadap kaum transeksual serta menjalin hubungan dengan harapan dapat menolong kaum transeksual terhindar dari perilaku dosa yang lebih jauh lagi. 


\section{DAFTAR PUSTAKA}

Buku

Alex Sobur, Pembinaan Anak Dalam Keluarga (jakarta: BPK Gunung Mulia, 1988)

Anton Bekker dan Achmad Charris Zubai, Metodelogi Penelitian Filsafat (Yogyakarta: Kanisius, 1990)

Aristoteles dalam Bertens, Etika (Jakarta: Gamedia Pustaka Utama, 1994)

Gary R. Collins, Konsoling Kristen yang Efektif (Malang, SAAT, 1990)

Gerald c Davison ,John M. naele, \& Ann m. Kring, Psikologi Abnormal Edisi 9 (Jakarta: Rajawali pers)

H. Soekahar, Hooseksualitas Tijauan Singkat Bedasarkan Iman Kristen (Yogyakarta: Andi, 1987)

J. Verkuyl, Etika Seksual (Jakarta: Badan Penerbit Kristen, 1963)

Kylem Yates, Tafsiran Alkitab Wycliffe Volume 1 PL kejadian sampai Ester (Bandung: Gamdum Mas 2004)

Norman L. Geisler, Etika Kristen Pilihan dan Isu, (malang: Literatur SAAT, 2003)

Robert P. Barrong. Etika Seksual Konteporel (Bandung: Ink Media, 2006)

Stanton L. \&brennaB. Jones, How and When To Tell Your Kids About Sex, Bagaimana dan Kapan Memberitahu Anak Anda Mengenai Seks, (Surabaya: Mementum 2004)

Supratiknya, Mengenal Prilaku Abnormal (Yogyakarta: Kanisius 1995)

Tim Bverly Lahaye, Kesidupan Seks dalam Pernikahan (Bandung: kalam Hidup, dan ANDI, 1976)

Tulus Tu’u, Etika dan Pendidikan Seksual (Bandung : Kalam Hidup, 1988) 


\section{Internet}

Diakses pada tanggal 19 juli 2010 tersedia di:

http://news.okezone.com/read/2009/12/30/345/289431/nadia-

menegaskan-status-diri-bertaruh-nyawa

George C. Scipione, The Biblical View Of The Body, diakses pada tanggal 7 april 2010 di www.ipdx.org/index.html

Hastening sakti, Mencari Kenyamanan Gender, diaakses tanggal 3maret 2010, tersedia di http://www.resep.web.id/seputar-sex/transeksual$\underline{\text { mencari-kenyamanan-genderhtm }}$

Transeksual, diakses tanggal 21 Februari, 2010, terssedia di http://roll.co.id/index.php/forum.html?func=view\&id=1362\&\&catid=29,

Transeksual, diakses pada tanggal lmaret 2010 terdapat di http://www.detiknews.com/read/2009/11/01/125909/1232704/10/gabu ngan-lsm-minta-polisi-penyiksa-rico-dihukum

The Effects of Sin on Sexuality, diakses pada tanggal 7 april 2010 terseduia di www.ipdx.org/index.html

George C. Scipione, The Biblical View Of The Body diakses pada tanggal 7 april 2010 di www.ipdx.org/index.html

Dedyriyadi, Bagaimana Memehami Waria, Diakses pada tanggal 27 mei 2010 tersedia di. http://sosbud.kompasiana.com/2010/05/05/bagaimana$\underline{\text { memahami-warial }}$ 